\title{
Enhancing Brand Loyalty Through Online Brand Community: The Role of Value Creation Process, Brand Love, and Trust
}

\section{Raditha Hapsari}

Department of Management, Faculty of Economics and Business, Universitas Brawijaya, Malang, Indonesia

\section{Abstract}

This study aims to investigate the interrelationships among value creation process, brand love, brand trust, and brand loyalty. The data were gathered from one hundred and fifty Nikon Camera's online brand community members, who were selected using purposive sampling, and were analyzed through Structural Equation Modelling. The results show that value creation process significantly affects trust, brand love, and brand loyalty. Furthermore, trust is proven affecting brand love and brand loyalty.

Corresponding Author: Raditha Hapsari raditha.hapsari@gmail.com raditha.hapsari@ub.ac.id

Received: 29 August 2018 Accepted: 18 September 2018 Published: 11 November 2018

Publishing services provided by Knowledge $\mathrm{E}$

(c) Raditha Hapsari. This article is distributed under the terms of

the Creative Commons

Attribution License, which permits unrestricted use and redistribution provided that the original author and source are credited.

Selection and Peer-review under the responsibility of the ICOI-2018 Conference Committee. As an emerging construct in marketing literature, brand love is found to have a significant role in enhancing the loyalty of on-line community members. The results imply that value creation process through online community is regarded as important in strengthening customers' loyalty toward a particular brand. Moreover, this current study suggests that brand loyalty will be higher when customers put more trust and fall in love with the brand. Despite the significance of the study, this current study has few limitations that can be overcome by future research as discussed in the last section of this article.

Keywords: value creation, trust, brand love, brand loyalty, on-line community

\section{Introduction}

Brand loyalty has been widely recognized as an important factor in the relationship marketing era. However, the predictors of brand loyalty may vary from time to time as a result of the changes in consumer behavior. Around a decade ago, researchers have found that value creation process as a part of relationship marketing is considered as an important construct in enhancing loyalty (Hapsari, Clemes, \& Dean, 2017). Nowadays, in the enhancement of information technology, value creation process is gaining more traction in literature as the process of creating value can be done offline and offline through social media or online communities.

Grönroos and Ravald (2011) contended that there should be two processes involved in value creation process. The first process is when the good or services providers 
are giving some resources for the customers, and the second process is when the customers are using the resources to co-create value. Building a brand community is an example of the effort that product/service providers do to facilitate consumers to enhance and co-create value. The value creation process taking place in an online community is believed to be paired with trust, as online brand community plays an important role on the behalf of the brand. By joining an online brand community, customers can obtain important information as well as build relationship with other members. By being part of the online brand communities, consumers can co-create value through community networking, community engagement, impression management, and brand use (Laroche, Habibi, Richard, \& Sankaranarayanan, 2012).

One of the objectives of value creation process is to establish relationship between customers and brand. Walter and Ritter (2003) noted that, in order to establish a strong and sustained relationships, there is a need to put trust in the relationship. When a customer has been interacting with the brand for quite a while, trust will appear in the relationship. Furthermore, once trust has been established in the relationship, emotional connection called brand love will emerge. The construct of brand love was derived from Stanberg's theory consisting of broad and long-term customer-brand relationships with affective, cognitive, and behavioral elements (Batra, Ahuvia, \& Bagozzi, 2012). The notion of brand love is considered as a new construct that has not been fully explored in marketing studies. Thus, there is a need to investigate the role of brand love in enhancing brand loyalty and its interrelationships with other marketing constructs.

This current research is expected to close gaps in literature. The integration of brand love as an emerging construct in marketing literature to the model will provide a more comprehensive insight about the interrelationships among constructs that have not been explored by other studies. Furthermore, this current research explains ways to enhance brand loyalty through value creation process by maximizing online community, trust, and brand love in the context of Indonesian customers.

\section{Literature Review}

\subsection{Brand loyalty}

Researches on brand loyalty have been extensively conducted in various industries. However, up to now the discussion on brand loyalty is still around marketing academics and practitioners. They agree that brand loyalty helps a business organization retain their customer and increase its profitability. Moreover, loyal customers also provide 
benefit for the company because they are more likely to defend and promote the company. As the advantages in building brand loyalty has been widely accepted, there is a need to explore the antecedents of brand loyalty.

\subsection{Value creation process}

Nowadays, the creation of value does not only rely on product and services providers; consumers also have important roles in creating value to match their wants and needs. Furthermore, (Laroche et al., 2012) noted that product and services providers together with its consumers can work together co-creating value and building firm's competitive strategy and innovation processes.

In the era of high information technology, where the value of communalities is getting stronger, consumers have the opportunity to create collective value through online community. Schau, Muñiz Jr, and Arnould (2009) found that brand communities help consumers create value through four steps: social networking, community engagement, brand use, and impression management (Laroche et al., 2012).

In relationship marketing practices, the more consumers interact with the brand in direct or indirect manner, the higher their likelihood to be loyal. Consumer's loyalty enhances when they get more opportunity to create value (Gruen, Osmonbekov, \& Czaplewski, 2007; Sirdeshmukh, Singh, \& Sabol, 2002). Thus, the following hypotheses are formulated.

H1: Value creation process positively and significantly affects brand loyalty.

$\mathrm{H}$ 2: Value creation process positively and significantly affects trust.

$\mathrm{H}_{3}$ : Value creation process positively and significantly affects brand love.

\subsection{Brand love}

While customer satisfaction is measured based on consumer's cognitive judgement, brand love is defined based on customer's affective judgement and long-term relationship with the brand (Carroll \& Ahuvia, 2006). Thus, brand love is defined as a passionate emotional connection of customers to a particular brand (Carroll \& Ahuvia, 2006). Customers who feel passionate and have emotional connection with a brand will not include expectancy disconfirmation to their evaluation on the brand consumption experiences. Thus, customers with high level of brand love tend to be highly loyal customers. Therefore, the following hypothesis is formulated. 
$\mathrm{H} 2$ : Brand love positively and significantly affects brand loyalty.

\subsection{Consumer trust}

Consumer trust is defined as the willingness of customers to rely on brand performance in satisfying their wants and needs (Chaudhuri \& Holbrook, 2001). Moreover, Chaudhuri and Holbrook (2001) also noted that consumer trust is regarded as the central determinant of loyalty. Thus, the following hypotheses are formulated.

H3: Trust positively and significantly affects brand loyalty.

H6: Trust positively and significantly affects brand loyalty.

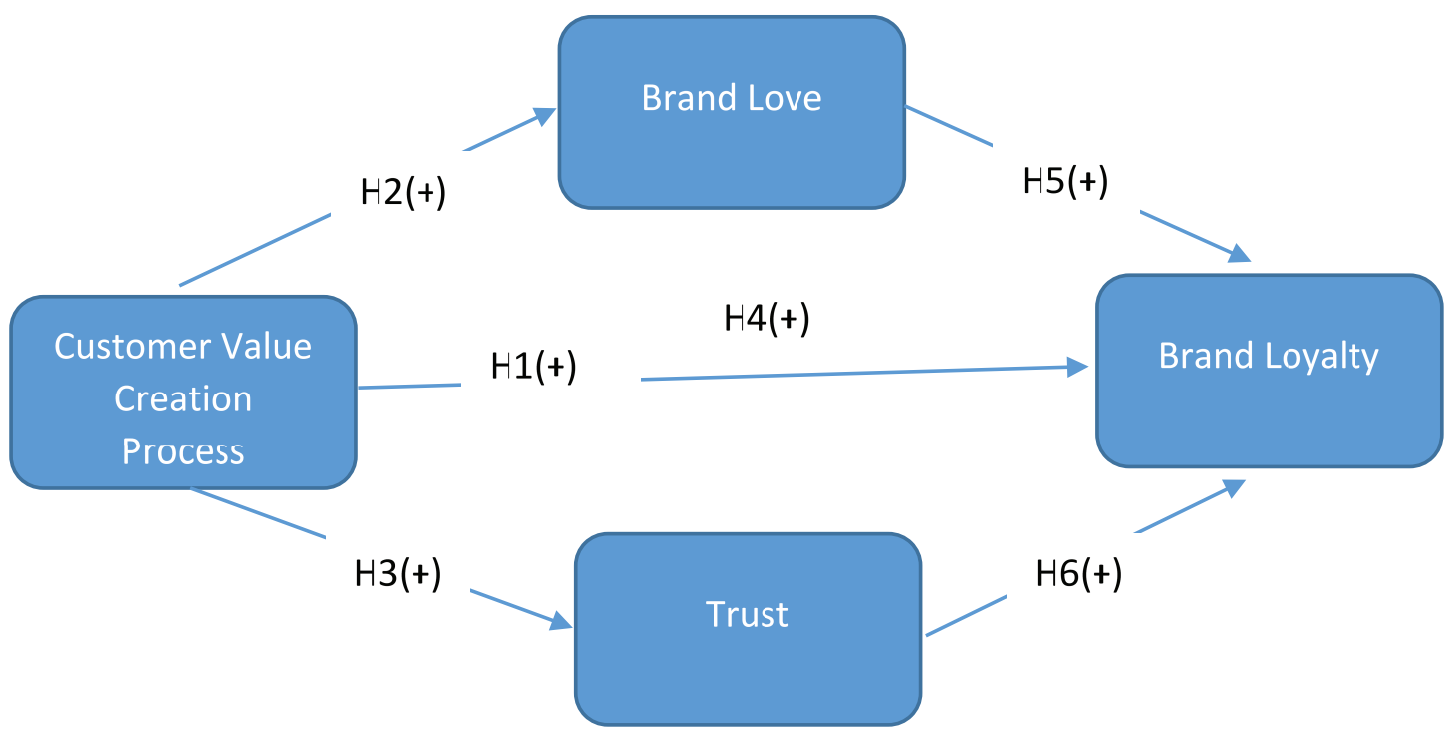

Figure 1: Conceptual research model.

\section{Research Method}

\subsection{Questionnaire development and data collection}

The constructs investigated in this study are operationalized through literature review. The questionnaire was built based on literature reviews and previous researches. Fivepoint Likert scale was used in the questionnaire, ranging from strongly disagree (point 1) to strongly agree (point 5).

Prior to the survey, a pilot study was conducted in order to avoid problems regarding scale validation, questionnaire design, and instruction. The first measure in the pilot test was checking the face validity by exposing the questionnaire to a panel consisting 
of marketing academicians and practitioners. This measure was done to ensure that the questionnaire have already captured the central issues around the investigated constructs.

The next step in the pilot study was distributing the questionnaire to 30 respondents and asking them to fulfil and give comments on the questionnaire. This was done to ensure that the statements for each item were clear and the instruction is easy to follow. Furthermore, a reliability test was conducted using data gathered from the pilot study. As the Cronbach's alpha scores were more than 0.7 , the questionnaire can be categorized as reliable and can be used to gather the data for hypothesis testing.

One hundred and fifty Nikon camera online community members participated in the survey, and the number was considered adequate for performing Structural Equation Modelling analysis. Purposive sampling was used to select the respondents, in which the requirements are as follows: (1) the respondents should be Nikon camera consumers, (2) the respondents should be a member of the Nikon team (official Nikon online community), and (3) the respondents have been a member of Nikon team for at least three months.

\subsection{Data analysis techniques}

Structural Equation Modelling (SEM) was used to test the hypothesis. The first step in the data analysis was conducting Confirmatory Factor Analysis (CFA) to ensure that the model is robust based on the model fit indices. Prior to the evaluation of model fit indices, the validity, reliability, and the uni-dimensionality of data were checked.

CFA was conducted to evaluate the model fit indices, including the absolute fit indices (chi-square, RMSEA, GFI and SRMR), incremental fit indices (CFI and NFI), and parsimonious fit index (PGFI). Once the goodness-of-fit model is achieved, the hypotheses are tested using AMOS 22.

The hypothesis testing in this study was conducted in two steps. The first step is testing the direct relationship between consumer value creation process, consumer trust, brand love, and consumer behavioral intention. The second step is testing the mediating role of consumer trust and brand love on the relationship between consumer value creation process and consumer behavioral intention.

\section{Results and Discussion}




\subsection{Respondents' profile}

The respondents participating in the survey are mostly male (87.3\%), 66\% of them are between 21 and 30 years old, and most of them are university students.

\subsection{Confirmatory factor analysis (CFA)}

Prior to the hypothesis testing, CFA was conducted in order to ensure that the model fit indices are above the recommended threshold. When the CFA was performed for the first time, the model fit indices were not acceptable. Therefore, there is a need to do model modification by deleting the items with factor loading of less than 0.5 or the items with high modification index score. By evaluating the factor loading and modification index scores, items $\mathrm{VC}_{1}, \mathrm{VC}_{2}, \mathrm{VC}_{4}, \mathrm{VC}_{5}$ and $\mathrm{VC} 8$ and also item $\mathrm{BT}_{4}$ were deleted from the model. Furthermore, as the standard error of items VC 6 and VC7 had high modification indices, those items were put together by drawing covariance between those two items, which means that both items are considered as one item in the model. After the model has been modified, CFA was performed and obtained adequate model fit indices $\left(x^{2} / d f=1.845, \mathrm{GFI}=0.875, \mathrm{PGFI}=0.624, \mathrm{RMSEA}=0.076\right.$, $\mathrm{NFI}=0.913$ and $\mathrm{CFI}=0.958)$. Table 1 Summaries the CFA results.

To ensure that the model is fit with the actual data, the construct reliability was evaluated by measuring the factor loading for each item and calculating its Average Variance Extracted (AVE). The cut off value for factor loading and AVE is 0.5 , which means that when factor loading values and AVE scores are more than 0.5 , the items and constructs in the model can be categorized as reliable. The factor loadings in this study range between 5.96 and 9.44; and the AVE scores range between 0.633 and 0.746 , which means that there is no problem with the construct reliability.

When evaluating the robustness of the proposed model, discriminant validity factor also needs to be evaluated. When the collinearity between two items is more than 0.85 , it means that the two items are suffering from discriminant validity problem. In this study, the collinearity scores are below 0.85 , meaning that there is no discriminant validity problem. 
TABLE 1: CFA results.

\begin{tabular}{|c|c|c|c|}
\hline Items & Factor Loadings & $\begin{array}{l}\text { Average Variance } \\
\text { Extracted (AVE) }\end{array}$ & $\begin{array}{c}\text { Composite } \\
\text { Reliability (CR) }\end{array}$ \\
\hline \multicolumn{4}{|c|}{ Value Creation } \\
\hline$V_{1}$ & 0.621 & & \\
\hline $\mathrm{VC}_{3}$ & 0.950 & 0.633 & 0.868 \\
\hline VC6 & 0.944 & & \\
\hline VC7 & 0.594 & & \\
\hline \multicolumn{4}{|c|}{ Brand Trust } \\
\hline $\mathrm{BT} 1$ & 0.848 & & \\
\hline $\mathrm{BT} 2$ & 0.871 & 0.694 & 0.871 \\
\hline $\mathrm{BT}_{3}$ & 0.778 & & \\
\hline \multicolumn{4}{|c|}{ Brand Love } \\
\hline BL1 & 0.865 & & \\
\hline $\mathrm{BL} 2$ & 0.897 & & \\
\hline $\mathrm{BL} 3$ & 0.869 & 0.746 & 0.936 \\
\hline $\mathrm{BL} 4$ & 0.844 & & \\
\hline $\mathrm{BL} 5$ & 0.844 & & \\
\hline \multicolumn{4}{|c|}{ Brand Loyalty } \\
\hline $\mathrm{BLOY}_{1}$ & 0.745 & & \\
\hline $\mathrm{BLOY}_{2}$ & 0.850 & & \\
\hline $\mathrm{BLOY}_{3}$ & 0.838 & 0.666 & 0.888 \\
\hline $\mathrm{BLOY}_{4}$ & 0.827 & & \\
\hline
\end{tabular}

\subsection{Hypothesis testing and discussions}

Six hypotheses were tested in this study. As the critical ratios for all hypothesis are more than 1.96 and all the path coefficients are positive, the hypothesis are supported. Table 2 summarizes the hypothesis testing results

TABLE 2: Results summary.

Hypothesis
Cust Value Creation Brand Trust
Cust Value Creation Brand Love
Customer Trust Brand Love
Customer Trust Brand loyalty
Cust Value Creation Brand loyalty
Brand Love Brand loyalty

\begin{tabular}{|c|c|c|c|}
\hline Estimate & C.R. & $\mathbf{P}$ & Label \\
\hline 0.454 & 4.719 & $\star \star \star$ & Supported \\
\hline 0.160 & 2.210 & 0.027 & Supported \\
\hline 0.700 & 8.253 & $\star \star \star$ & Supported \\
\hline 0.409 & 4.160 & $\star \star \star *$ & Supported \\
\hline 0.211 & 3.378 & 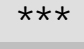 & Supported \\
\hline 0.422 & 4.421 & $\star \star \star *$ & Supported \\
\hline
\end{tabular}

Customer value creation process, customer trust, and brand love are found to affect brand loyalty. These findings are important for marketing and consumer behavior 
literature, as those antecedents of brand loyalty have only been investigated in very few studies.

The hypothesis testing found that brand loyalty is affected by customer value creation process, customer trust, and brand love. Brand love is proven as the most influential construct in enhancing brand loyalty, which is supported by previous studies such as those by Bergkvist and Bech-Larsen (2010), Batra et al. (2012), and Carroll and Ahuvia (2006). Brand love as an important marketing construct is gaining more traction in marketing and consumer behavior literature, as brand love can capture customers' feeling and emotion toward a brand. The positive slope of the impact of brand love on brand loyalty means that the more customers love and feel passionate about a particular brand, the more positive their post-consumption behavior becomes, such as repurchase intention and word of mouth (Bergkvist \& Bech-Larsen, 2010).

The other two endogenous constructs (customer trust and brand love) investigated in this study also have positive and significant effects on brand loyalty. The higher the customer's involvement in value creation process, the higher his loyalty to the brand. Customer value creation process is found to be an important factor in enhancing brand loyalty through higher repurchase intention and word of mouth. The role of customer value creation process as in enhancing brand loyalty has been conducted in financial service industry (Auh, Bell, McLeod, \& Shih, 2007), in Korean Airline Service (Chen and Wang, 2016), and in three service industries (Stokburger-Sauer, Scholl-Grissemann, Teichmann, and Wetzels 2016).

Brand love as an emerging construct in marketing studies is also found to have an essential role in increasing brand loyalty. The more customers feel passionate toward a particular brand, the higher their brand loyalty.

As brand love is a marketing construct which captures the emotional feeling customers have toward a particular brand, and it is proven affecting brand loyalty, there is a need to explore the antecedent of brand love. This study shows that customer value creation process and customer trust positively and significantly affect brand love. Customer value creation process is an important aspect that will lead to a higher intimacy and a more passionate feeling toward a brand. One of the processes in creating value that is done by customers is joining online community and actively participating in that community. The more customers feel accepted as a part of the online community, the more their enthusiasm and passionate feeling toward the brand. Thus, in order to enhance brand love, a company with online community has to make sure that every member can easily participate in the community and make sure that each member is treated equally. This finding is supported by the study of Vernuccio (2014). 
Brand trust is another construct that is proven being an antecedent of brand love. The more a customer trusts a particular brand, the higher the love toward the brand. This finding is supported by previous researches (Albert \& Merunka, 2013; Batra et al., 2012; P. Becerra \& Badrinarayanan, 2013), which noted that brand trust will result in long-term customer-brand relationships. One of the manifestation of the relationship is brand love. Thus, in order to create brand love among customers, a company must ensure that they trust the brand and feel confidence that the brand can fulfil their needs and wants.

\section{Conclusion and Suggestion for Future Research}

This current research has found that brand loyalty is not merely affected by widely known marketing constructs, but also by emerging construct such as brand love. Furthermore, this research also noted that customer value creation process and trust are the antecedents of brand love, which is also found to be the constructs that will enhance brand loyalty.

To get a deeper understanding about the interrelationship among customer value creation process, brand love, trust, and brand loyalty, future research should investigate the indirect effect established in the model. Furthermore, adding a moderating variable, such as gender or hedonic/utilitarian motivation, will enrich the insight about the relationship among the constructs.

\section{References}

[1] Albert, N. and Merunka, D. (2013). The role of brand love in consumer-brand relationships. Journal of Consumer Marketing, vol. 30, no. 3, pp. 258-266.

[2] Auh, S., Bell, S. J., McLeod, C. S., et al. (2007). Co-production and customer loyalty in financial services. Journal of Retailing, vol. 83, no. 3, pp. 359-370.

[3] Batra, R., Ahuvia, A., and Bagozzi, R. P. (2012). Brand love. Journal of Marketing, vol. 76, no. 2, pp. 1-16.

[4] Bergkvist, L. and Bech-Larsen, T. (2010). Two studies of consequences and actionable antecedents of brand love. Journal of Brand Management, vol. 17, no. 7, pp. 504-518.

[5] Carroll, B. A. and Ahuvia, A. C. (2006). Some antecedents and outcomes of brand love. Marketing Letters, vol. 17, no. 2, pp. 79-89. 
[6] Chaudhuri, A. and Holbrook, M. B. (2001). The chain of effects from brand trust and brand affect to brand performance: The role of brand loyalty. Journal of Marketing, vol. 65 , no. 2, pp. 81-93.

[7] Chen, C.-F. and Wang, J.-P. (2016). Customer participation, value co-creation and customer loyalty-A case of airline online check-in system. Computers in Human Behavior, vol. 62, pp. 346-352.

[8] Grönroos, C. and Ravald, A. (2011). Service as business logic: Implications for value creation and marketing. Journal of Service Management, vol. 22, no. 1, Pp. 5-22.

[9] Gruen, T. W., Osmonbekov, T., and Czaplewski, A. J. (2007). Customer-to-customer exchange: Its MOA antecedents and its impact on value creation and loyalty. Journal of the Academy of Marketing Science, vol. 35, no. 4, pp. 537-549.

[10] Hapsari, R., Clemes, M. D., and Dean, D. (2017). The impact of service quality and customer engagement and selected marketing constructs on airline passenger loyalty. International Journal of Quality and Service Sciences, vol. 9, no. 1.

[11] Laroche, M., Habibi, M. R., Richard, M.-0., et al. (2012). The effects of social media based brand communities on brand community markers, value creation practices, brand trust and brand loyalty. Computers in Human Behavior, vol. 28, no. 5, pp. 1755-1767.

[12] P. Becerra, E. and Badrinarayanan, V. (2013). The influence of brand trust and brand identification on brand evangelism. Journal of Product \& Brand Management, vol. 22, nos. 5/6, pp. 371-383.

[13] Schau, H. J., Muñiz Jr, A. M., and Arnould, E. J. (2009). How brand community practices create value. Journal of Marketing, vol. 73, no. 5, pp. 30-51.

[14] Sirdeshmukh, D., Singh, J., and Sabol, B. (2002). Consumer trust, value, and loyalty in relational exchanges. Journal of Marketing, vol. 66, no. 1, pp. 15-37.

[15] Stokburger-Sauer, N. E., Scholl-Grissemann, U., Teichmann, K., et al. (2016). Value cocreation at its peak: The asymmetric relationship between coproduction and loyalty. Journal of Service Management, vol. 27, no. 4, Pp. 563-590.

[16] Vernuccio, M. (2014). Communicating corporate brands through social media: An exploratory study. International Journal of Business Communication, vol. 51, no. 3, pp. 211-233.

[17] Walter, A. and Ritter, T. (2003). The influence of adaptations, trust, and commitment on value-creating functions of customer relationships. Journal of Business \& Industrial Marketing, vol. 18, nos. 4/5, pp. 353-365. 